\title{
Molecular Characterization and Expression Analysis of Clathrin-Associated Adaptor Protein 3- $\delta$ Subunit 2 (AP3S2) in Chicken
}

\author{
Jae-Don $\mathrm{Oh}^{1}$, Godfrey Bigirwa ${ }^{2}$, Seokhyun Lee ${ }^{1}$ and Ki-Duk Song ${ }^{1,2,3^{\dagger}}$ \\ ${ }^{I}$ Research Professor/Research Professor, Department of Animal Biotechnology, College of Agricultural and Life Sciences, \\ Chonbuk National University, Jeonju 54896, Republic of Korea \\ ${ }^{2}$ Graduate student, Department of Agricultural Convergences, College of Agricultural and Life Sciences, \\ Chonbuk National University, Jeonju 54896, Republic of Korea \\ ${ }^{3}$ Professor, The Animal Molecular Genetics and Breeding Center, Chonbuk National University, Jeonju 54896, Republic of Korea
}

\begin{abstract}
A chicken clathrin-associated adaptor protein 3- $\delta$ subunit 2 (AP3S2) is a subunit of AP3, which is involved in cargo protein trafficking to target membrane with clathrin-coated vesicles. AP3S2 may play a role in virus entry into host cells through clathrin-dependent endocytosis. AP3S2 is also known to participate in metabolic disease developments of progressions, such as liver fibrosis with hepatitis $\mathrm{C}$ virus infection and type 2 diabetes mellitus. Chicken AP3S2 (chAP3S2) gene was originally identified as one of the differentially expressed genes (DEGs) in chicken kidney which was fed with different calcium doses. This study aims to characterize the molecular characteristics, gene expression patterns, and transcriptional regulation of chAP3S2 in response to the stimulation of Toll-like receptor 3 (TLR3) to understand the involvement of chAP3S2 in metabolic disease in chicken. As a result, the structure prediction of chAP3S2 gene revealed that the gene is highly conserved among AP3S2 orthologs from other species. Evolutionarily, it was suggested that chAP3S2 is relatively closely related to zebrafish, and fairly far from mammal AP3S2. The transcriptional profile revealed that chAP3S2 gene was highly expressed in chicken lung and spleen tissues, and under the stimulation of poly (I:C), the chAP3S2 expression was down-regulated in DF-1 cells $(P<0.05)$. However, the presence of the transcriptional inhibitors, BAY 11-7085 (Bay) as an inhibitor for nuclear factor $\mathrm{kB}(\mathrm{NF} \mathrm{kB})$ or Tanshinone IIA (Tan-II) as an inhibitor for activated protein 1 (AP-1), did not affect the expressional level of chAP3S2, suggesting that these transcription factors might be dispensable for TLR3 mediated repression. These results suggest that $\operatorname{chAP} 3 S 2$ gene may play a significant role against viral infection and be involved in TLR3 signaling pathway. Further study about the transcriptional regulation of chAP3S2 in TLR3 pathways and the mechanism of chAP3S2 upon virus entry shall be needed.
\end{abstract}

(Key words: AP3S2, chicken, differentially expressed genes, toll-like receptor 3, transcriptional regulation)

\section{INTRODUCTION}

Clathrin is a protein coating the protein transport vesicles budded out of the plasma membrane (endocytosis) and functioning as cargo selection. In cellular transport, the endocytosis is the major route of the protein import into a cell including extracellular hormones, signal factors, receptor proteins, and synaptic membrane proteins. These protein transports are guided by the specific coat proteins with clathrin coat involved in vesicle budding and report sorting (Le Roy and Wrana, 2005). In the clathrin-dependent endocytosis, protein vesicles about $100 \mathrm{~nm}$ in diameter are surrounded with a crystalline coat containing the clathrin protein and clathrin adaptor proteins. Clathrin protein works as the scaffold for transport proteins and lipids that are bound to clathrin adaptor proteins (Kaksonen and Roux, 2018). One of the major clathrin adaptor complexes, clathrin-associated adaptor protein (AP) complex, is a cytosolic heterotetramer that promotes the assembly and trafficking of clathrin coat vesicles by connecting the cargos to the clathrin protein. In mammals, there are five adaptor proteins, AP-1, AP-2, AP-3, AP-4, and AP-5, expressed in different subcellular compartments. The APs bind integral membrane cargo proteins and put them into coated membrane domains. These coated cargo proteins are further transported to specific target organelles (Hirst et al., 2011).

\footnotetext{
${ }^{\dagger}$ To whom correspondence should be addressed : kiduk.song@gmail.com
} 
AP3 complex is ubiquitously expressed heterotetrameric complex which consists of $\beta 3 \mathrm{~A}, \mu 3 \mathrm{~A}, \sigma 3$, and $\delta$ subunits. It is known to recruit clathrin and responsible for protein trafficking to target membrane with clathrin-coated vesicles budded out of the endosomes (Robinson, 2004). One of the $\delta$ subunits, AP3S2, is so far known to mediate liver fibrosis and liver cirrhosis with hepatitis $\mathrm{C}$ virus infection ( $\mathrm{Li}$ et al., 2009). Also, AP3S2 involved in regulating the vesicle transport in several tissues including adipocytes and pancreatic cells. It has been reported that AP3S2 is associated with type 2 diabetes mellitus, but the exact mechanism is not clearly ascertained yet (Kooner et al., 2011; Fukuda et al., 2012; Kazakova et al., 2017). It is also known that virus enters the host cells through clathrin-dependent endocytosis by mimicking the endogenous ligands to the host cell receptors (Mercer et al., 2010). In 2008, Krishnan et al. reported that the entry of West Nile virus is through clathrin dependent endocytosis and the endocytosis can be inhibited by RNA interference of clathrin adaptor AP3S2 (Kirchhausen et al., 2014).

Pathogen-associated molecular patterns (PAMPs), including polyinosinic-polycytidylic acid (poly [I:C]) and lipopolysaccharide (LPS), are recognized by Toll-like receptors (TLRs) and activate the innate immune system. Poly (I:C) is a synthetic analogue of double-stranded RNA (dsRNA) which is generated during the replication of viruses, and it can be recognized by endosomal TLR3 ligands as much as virusderived dsRNA (Alexopoulou et al., 2001; Nishiya et al., 2005; Weber et al., 2006). Upon the recognition of poly (I:C), TLR3 can initiate of the innate immune system such as inflammatory response which is normally activated against viral infection. In fowls, it was reported that during the viral infection, the expression levels of TLR3 and other cytokines are increased and TLR3 activates the innate immune responses (Cheng et al., 2014; Zhang et al., 2015).

This study was conducted to analyze the amino acid sequence encoded by chicken AP3S2 (chAP3S2) and to investigate the gene expression of chAP3S2 upon the stimulation by poly (I:C) mimicking TLR3 ligand. The transcriptional regulation of $c h A P 3 S 2$ was also evaluated with the inhibitors of nuclear factor $\mathrm{\kappa B}(\mathrm{NF \kappa B})$ and activated protein 1 (AP-1) in chicken DF-1 cells.

\section{MATERIALS AND METHODS}

\section{Cell Culture}

The chicken cell line DF-1 (ATCC, CRL-12203) was purchased from the American Tissue Culture Collection (ATCC, Manassas, VA, USA). DF-1 cells were grown in Dulbecco's modified Eagle's medium (DMEM), purchased from Biowest (Riverside, MO, USA), supplemented with $10 \%$ fetal bovine serum (FBS), $2 \mathrm{mM} \mathrm{L}$-glutamine and $100 \mathrm{U} / \mathrm{mL}$ each of penicillin and streptomycin (Thermo Fisher Scientific, Waltham, MA, USA) at $37^{\circ} \mathrm{C}$ in a humidified atmosphere of $5 \% \mathrm{CO}_{2}$ and $95 \%$ air.

\section{Treatment of Poly $(\mathrm{I}: \mathrm{C})$ and Transcription Factor Inhibitors}

Poly (I:C) was purchased from Invivogen (San Diego, CA, USA) and treated in chicken DF-1 cells at the concentrations of $0.1 \mu \mathrm{g} / \mathrm{mL}, 1 \mu \mathrm{g} / \mathrm{mL}, 5 \mu \mathrm{g} / \mathrm{mL}$, and $10 \mu \mathrm{g} / \mathrm{mL}$ for $24 \mathrm{~h}$. The timely effect of poly (I:C) was determined by treating for $1 \mathrm{~h}, 3 \mathrm{~h}, 6 \mathrm{~h}, 12 \mathrm{~h}$, and $24 \mathrm{~h}$ at $10 \mu \mathrm{g} / \mathrm{mL}$ concentration before the analysis of gene expression. BAY 11-7085 (BAY, inhibitor of transcription factor $\mathrm{NFKB}$ ) and Tanshinone-IIA (Tan-II, AP-1 inhibitor) were purchased from Sigma-Aldrich (Louis, MO, USA). The inhibitors were treated on DF-1 cells with the concentrations of $5 \mu \mathrm{M}$ for BAY 11-7085, and 25 $\mu \mathrm{M}$ for Tanshinone IIA at $3 \mathrm{~h}$ before the treatment of $5 \mu \mathrm{g} / \mathrm{mL}$ poly (I:C).

\section{Bioinformatic Analysis}

The AP3S2 mRNA and amino acid sequences of various species (chicken, zebrafish, human, mouse, rat, cow, pig, horse, dog, and cat) were retrieved from the Ensemble database (http://www.ensembl.org/) (Table 1). The amino acid sequences were aligned with the ClustalW method in the BioEdit software. The protein domains were predicted by using the SMART domain search program (http://smart.emblheidelberg.de/). Phylogenetic analyses were performed with MEGA7 software (Kumar et al., 2016).

\section{RNA Extraction and cDNA Synthesis}

Total RNA of chicken DF-1 cell was isolated with Trizol 
Table 1. Amino acid sequence ID in the $A P 3 S 2$ gene of various species

\begin{tabular}{ccc}
\hline \hline Species & Scientific name & $\begin{array}{c}\text { NCBI Reference } \\
\text { Sequence ID }\end{array}$ \\
\hline Chicken & Gallus gallus & NM_001291731.1 \\
Human & Homo sapiens & NM_005829.4 \\
Chimpanzee & Pan troglodytes & XM_009429760.2 \\
Mouse & Mus musculus & NM_009682.3 \\
Rat & Rattus norvegicus & NM_001115039.1 \\
Cow & Bos taurus & NM_001075376.1 \\
Pig & Sus scrofa & NM_001244548.1 \\
Dog & Canis & XM_005618255.3 \\
Cat & Felis catus & XM_003986807.3 \\
\hline
\end{tabular}

reagent (Life Technologies, Carlsbad, CA, USA) according to the manufacturer's instructions. Total RNA levels were quantified at $260 \mathrm{~nm}$ by NanoDrop spectrophotometer (Thermo Fisher Scientific, Waltham, MA, USA) and RNA integrity was evaluated by $1.0 \%(\mathrm{w} / \mathrm{v})$ agarose gel. For RT-PCR, $2 \mu \mathrm{g}$ of total RNA was reverse transcribed into cDNA using QuantiTect Reverse Transcription Kit (Toyobo, Osaka, Japan) according to the manufacturer's instructions.

\section{Quantitative Real-time Polymerase Chain Reaction (qRT-PCR) Analysis}

For the analysis of chAP3S2 expression, quantitative realtime-PCR (qRT-PCR) was performed with SYBR green supermix using CFX96 $^{\mathrm{TM}}$ IVD Real-time PCR System (Bio-rad, Hercules, CA, USA). The sequences of the chAP3S2 primers were 5'-GTG CTG GAA ACC AAC ATG AA-3' for the forward primer and 5'-ATG TTG ATG TCC CCG ATG TT-3' for the reverse primer. ChIL1B primers were: 5'-GGA TTC TGA GCA CAC CAC AGT-3' (forward) and 5'-TCT GGT TGA TGT CGA AGA TGT C-3' (reverse). ChIL8 primers were: 5'-CCA AGC ACA CCT CTC TTC CA-3' (forward) and 5'-GCA AGG TAG GAC GCT GGT AA-3' (reverse). The PCR conditions were as follows: an initial step at $94^{\circ} \mathrm{C}$ for $3 \mathrm{~min} ; 39$ cycles at $94^{\circ} \mathrm{C}$ for $10 \mathrm{~s}, 60^{\circ} \mathrm{C}$ for 30 $\mathrm{s}$, and $72^{\circ} \mathrm{C}$ for $30 \mathrm{~s}$; and a final step at $72^{\circ} \mathrm{C}$ for $10 \mathrm{~min}$. Dissociation was performed at $0.5^{\circ} \mathrm{C}$ increments from $55^{\circ} \mathrm{C}$ to $95^{\circ} \mathrm{C}$ for over $25 \mathrm{~min}$. Relative quantification analysis was performed using the comparative $\mathrm{Ct}\left(2^{(-\Delta \Delta \mathrm{CT})}\right)$ method. The expression of glyceraldehyde-3-phosphate dehydrogenase (GAPDH) was used as endogenous control for the detection of mRNA expression levels. The sequences of GAPDH primers are: 5'- TGC TGC CCA GAA CAT CAT CC -3 ' for forward primer and 5'- ACG GCA GGT CAG GTC AAC AA -3 ' for reverse primer.

\section{Statistical Analysis}

The results were presented as the mean \pm standard deviation of at least three independent experiments. Statistical significance was evaluated using Student's $t$-test. Compared to the vehicle control, $P<0.05$ were considered significant. The difference among each value was determined by Tukey's test with alpha $<0.05$.

\section{RESULTS AND DISCUSSION}

The amino acid sequence of chAP3S2 was analyzed and compared with other species. The chAP3S2 gene sequence was identified as a DEG from chicken kidney RNA-seq analysis, that chickens were fed with different amount of calcium (Park et al., 2017). The amino acid sequences of chicken AP3S2 gene was also compared with AP3S2 orthologs from other species including zebrafish, horse, dog, cat, mouse, rat, pig, cow, human and chimpanzee, which were retrieved from Ensemble database (Fig. 1A). It was found that AP3S2 was highly conserved among the species based on the detection with SignalP v4.0 program (http://www.cbs.dtu.dk/) and the evolutionary relationships between chAP3S2 and other AP3S2 orthologs were analyzed by phylogenetic tree (Fig. 1B). Based on the amino acid sequence alignment, chAP3S2 was relatively closely related to zebrafish, and fairly far from mammal AP3S2.

The gene expression pattern of chicken AP3S2 was investigated in various chicken tissues. It was turned out that chAP3S2 gene was highly expressed in chicken lung and spleen tissues (Fig. 2A). The physiological role of chAP3S2 in lung is not clear yet and further study is needed to understand its role in the inflammatory condition as well as 
(A)
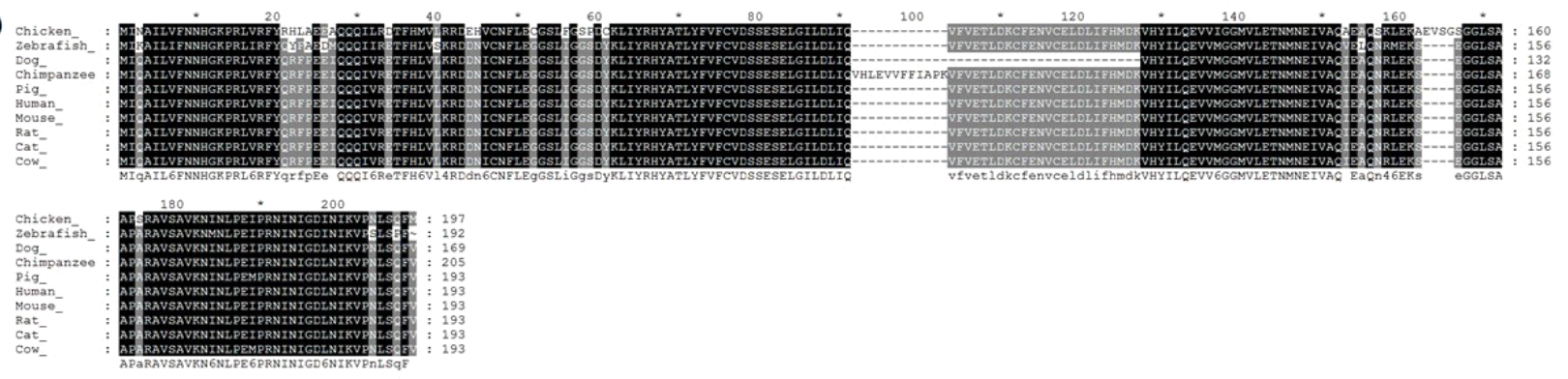

(B)

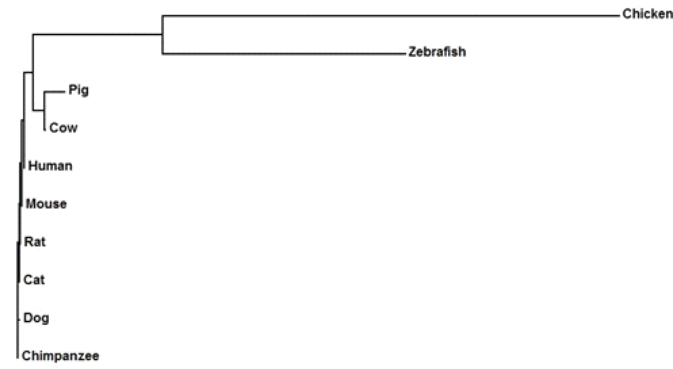

品

Fig. 1. Analysis of AP3S2 amino acid sequences. (A) Alignment of amino acid sequences of the chicken $A P 3 S 3$ gene in various species. (B) Phylogenetic tree for AP3S2 from various species. Phylogenetic analyses were performed with the amino acid sequence of each species, using MEGA7 software.

(A)

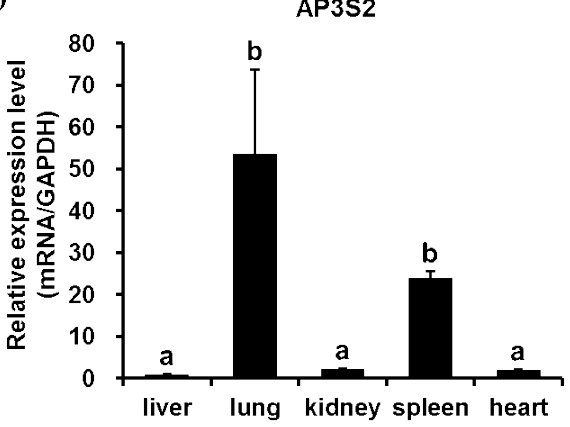

(B)

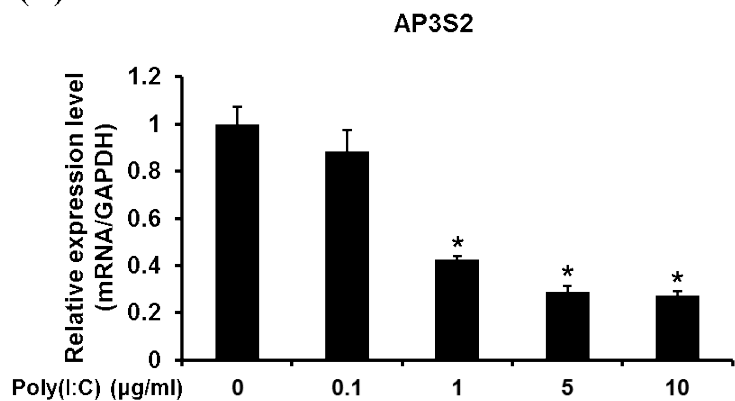

(C)

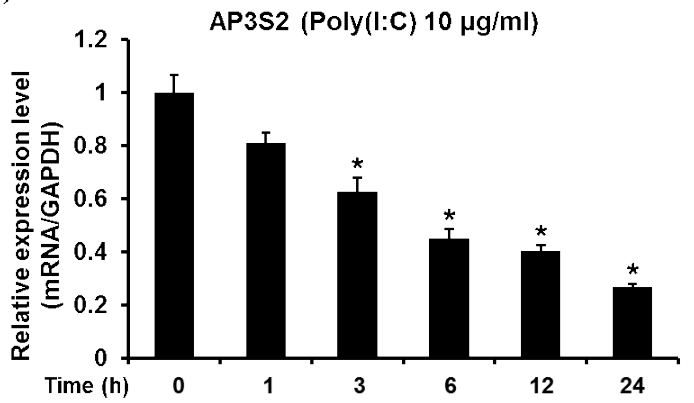

Fig. 2. (A) Analysis of expression levels of chAP3S2 in different chicken tissues (liver, lung, kidney, spleen, and heart). (B) The expression of chAP3S2 in chicken DF-1 cells after treatment with $0.1 \mu \mathrm{g} / \mathrm{mL}, 1 \mu \mathrm{g} / \mathrm{mL}, 5 \mu \mathrm{g} / \mathrm{mL}, 10 \mu \mathrm{g} / \mathrm{mL}$ of poly (I:C) for 24 h. (C) DF-1 cells were treated with $10 \mu \mathrm{g} / \mathrm{mL}$ poly (I:C) for $1 \mathrm{~h}, 3 \mathrm{~h}, 6 \mathrm{~h}, 12 \mathrm{~h}$ and $24 \mathrm{~h}$.

The experiment was repeated for three times $(\mathrm{n}=3)$. Significant differences were determined by Tukey's test, and ${ }^{*}$ means $P<0.05$. 
in the normal condition. The transcriptional profile of chicken AP3S2 was also investigated in chicken DF1 cells under the stimulation with TLR-3 agonist, poly (I:C), which is structurally similar to dsRNA and thus used for simulating the viral infection. Surprisingly, the expressional level of chAP3S2 gene after stimulation of poly (I:C) was negatively regulated (Fig. 2B). Poly (I:C) stimulation was examined both in dosage-dependent and time-dependent manner. As shown in Fig. 2C, chAP3S2 expression began to be reduced after 24-hour treatment of $1 \mu \mathrm{g} / \mathrm{mL}$ of poly (I:C); which means poly (I:C) stimulation is responsible for the down-regulation of $c h A P 3 S 2$ gene. For the time-dependent stimulation by poly (I:C) shown in Fig. 2D, the expressional level of chAP3S2 gene began to be decreased in $1 \mathrm{hr}$ after treatment of $10 \mu \mathrm{g} / \mathrm{mL}$ of poly (I:C). To verify the reduced expression of chAP3S2 gene is regulated by TLR3 signaling, the expression of chILIB and chIL8, which are known to be involved in TLR3 signaling pathway was investigated. As shown in Fig. 3B and $\mathrm{C}$, the transcriptional level of both chicken genes were all up-regulated after treatment of $5 \mu \mathrm{g} / \mathrm{mL}$ of poly (I:C) which means the expression of ChILIB and chIL 8 were induced by poly (I:C) stimulation and they are under control of TLR3 signaling pathway in chicken. This result proposes that although the exact path is not clear, chAP3S2 expression may be reduced upon the virus entry in chicken cell and this leads to possibility that $\operatorname{chAP} 3 S 2$ may be related to the TLR3- mediated innate immune responses.

To confirm whether this down-regulation of chAP3S2 is due to TLR signaling, transcriptional inhibitors of TLR3 signal pathway was also added in chicken DF-1 cell before poly (I:C) treatment. NF- $\mathrm{kB}$ and AP-1 are the transcriptional factors involved in TLR3 signal pathway and their wellknown inhibitors are Bay and Tan-II, respectively. After six hours from $5 \mu \mathrm{g} / \mathrm{mL}$ poly (I:C) treatment under the presence of Bay or Tan-II, the expressional level of chIL1B and chIL8 were evaluated. Both inhibitors were added at three hours prior to the poly (I:C) treatment. As shown in Fig. 3, without the inhibitors, only the transcriptional level of chAP3S2 was reduced while chILIB and chIL8; were up-regulated after treatment of $5 \mu \mathrm{g} / \mathrm{mL}$ of poly (I:C). As expected, the up-regulations of chILIB and chIL8 genes were significantly suppressed under the presence of transcriptional inhibitors, but the transcriptional levels of chAP3S2 did not change even with the addition of the inhibitors. The result suggests that unlike the $\operatorname{chILIB}$ and chIL8, the transcriptional factors NF-K $\mathrm{B}$ and AP-1 might be dispensable for the transcription of chAP3S2, although it is negatively regulated under the stimulation of poly (I:C). It is somewhat intriguing because both transcriptional factors are known to control the transcription of target genes including cytokines by TLR3 signaling in chicken. Although further study is needed, it is suspected that the expression of chAP3S2 in TLR3 signaling
(A)

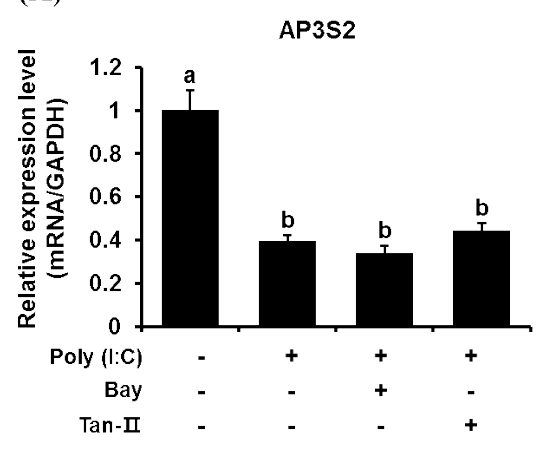

(B)

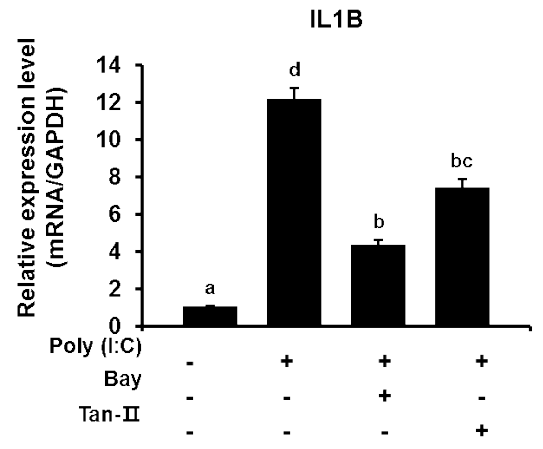

(C)

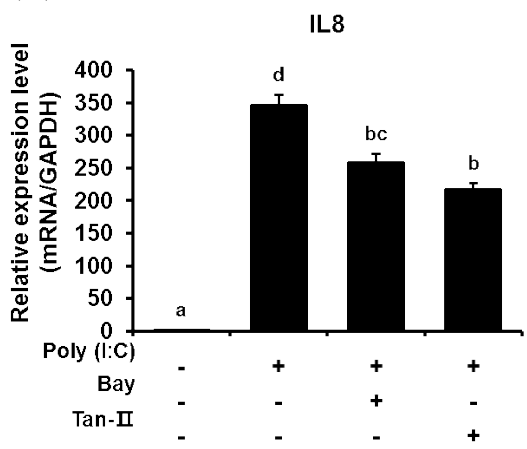

Fig. 3. Effects of NFKB inhibitor (BAY11-7085; Bay) and AP-1 inhibitor (Tanshinone IIA; Tan-II) on the gene expression of (A) chAP3S2, (B) chIL1B, and (C) chIL8 after stimulation with poly (I:C) in the cultured DF-1 fibroblast cells.

Cultured DF-1 cells were treated with or without poly (I:C) $(5 \mu \mathrm{g} / \mathrm{mL}, 6 \mathrm{~h})$ in the presence or absence of Bay $(5 \mu \mathrm{M})$ and Tan-II $(25$ $\mu \mathrm{M})$. Values are mean $\pm \mathrm{SE}(\mathrm{n}=3)$. Significant differences were determined by Tukey's test, and bars with the same letter $(\mathrm{a} \sim \mathrm{d})$ on top are the cases that significant differences were not found (alpha $<0.05)$. 
pathway may be regulated by transcription factors other than $\mathrm{NF}-\kappa \mathrm{B}$ and AP-1 in chicken.

The genetic information and expression patterns of chAP3S2 gene presented in this study can provide the fundamental information for further understanding of chAP3S2 on the involvement in chicken innate immune response. The down-regulation of chAP3S2 under the TLR3 agonists, poly (I:C) suggests that this gene may play a significant role against viral infection in chicken and thus gene may be useful as a candidate biomarker for infectious diseases in chickens.

\section{적 요}

닭의 clathrin-associated adaptor protein $3-\delta$ subunit 2 (AP3S2)는 clathrin-coated vesicle를 가진 표적 세포막으로 암 배양 단백질 수송에 관여한다. $\mathrm{AP} 3 \mathrm{~S} 2$ 는 $\mathrm{C}$ 형 간염 바이 러스 감염으로 간 섬유화를 매개하고, 2형 당뇨병과 관련이 있는 것으로 알려져 있다. 또한, $\mathrm{AP} 3 \mathrm{~S} 2$ 는 clathrin-dependent endocytosis를 통해 숙주 세포로의 바이러스 유입에 관련된 역할을 하는 것으로 알려져 있다. 본 연구는 기존 연구에서 닭 신장조직에서 차별 발현 유전자로 발굴된 닭 $A P 3 S 2$ 유전 자의 분자유전학적 특성을 구명하고, 닭의 조직에서의 유전 자 발현 양상을 조사하며, 톨-유사수용체 3 (Toll-like receptor 3 ; TLR3) 자극에 의한 전사 조절을 연구하였다. 닭 $A P 3 S 2$ 유전자가 코딩하는 단백질의 구조는 다른 종과 매우 보존적 이고 진화적으로 제브라 피쉬와 가장 가깝고, 포유류와 가 장 먼 것으로 추정되었다. 닭의 다양한 조직에서 닭 $A P 3 S 2$ 유전자의 전사 수준을 조사한 결과, 폐에서 가장 높게 발현 되었으며, 그 다음은 비장 순이었다. 닭의 배아 섬유아세포 주인 $\mathrm{DF}-1$ 세포에서 조사한 결과, $A P 3 S 2$ 유전자의 발현은 $\mathrm{TLR} 3$ 신호자극에 의해 감소하였다. 전사조절인자인 $\mathrm{NFkB}$ 나 $\mathrm{AP}-1$ 의 억제제를 이용하여 조사한 결과, NFkB나 AP-1 의 억제에 의해 유전자 발현이 영향을 받지 않았다. 이 결과 는 DF-1 세포에서 닭 $A P 3 S 2$ 유전자의 발현은 적어도 이 두 전사조절인자와는 독립적인 경로에 의해 조절됨을 시사한 다. 본 연구의 결과는 닭 $\mathrm{AP} 3 \mathrm{~S} 2$ 가 바이러스 감염에 역할을 하고, TLR3 신호에 관여함을 제시한다. 추가연구를 통해 닭 $A P 3 S 2$ 의 전사 조절과 바이러스 침입 메커니즘을 구명할 필 요가 있다고 사료된다.

(색인어: 닭, $\mathrm{AP} 3 \mathrm{~S} 3$, 단백질 구조, 유전자 발현, 선천성 면
역 수용체 신호전달)

\section{ACKNOWLEDGMENTS}

This work was supported by a grant from the NextGeneration BioGreen 21 Program (No. PJ01324201, PJPJ013 15101), Rural Development Administration, Republic of Korea.

\section{REFERENCES}

Alexopoulou L, Holt AC, Medzhitov R, Flavell RA 2001 Recognition of double-stranded RNA and activation of NF-kappaB by toll-like receptor 3. Nature 413(6857): $732-738$

Cheng J, Sun Y, Zhang X, Zhang F, Zhang S, Yu S, Qiu X, Tan L, Song C, Gao S, Wu Y, Ding C 2014 Toll-like receptor 3 inhibits Newcastle disease virus replication through activation of pro-inflammatory cytokines and the type-1 interferon pathway. Arch Virol 159(11):2937-2948.

Fukuda H, Imamura M, Tanaka Y, Iwata M, Hirose H, Kaku $\mathrm{K}$, Maegawa $\mathrm{H}$, Watada $\mathrm{H}$, Tobe $\mathrm{K}$, Kashiwagi A, Kawamori R, Maeda S 2012 A single nucleotide polymorphism within DUSP9 is associated with susceptibility to type 2 diabetes in a Japanese population. PLoS One 7(9):e46263.

Hirst J, Barlow LD, Francisco GC, Sahlender DA, Seaman MN, Dacks JB, Robinson MS 2011 The fifth adaptor protein complex. PLoS Biol 9(10):e1001170.

Kaksonen M, Roux A 2018 Mechanisms of clathrin-mediated endocytosis. Nat Rev Mol Cell Biol 19(5):313-326.

Kazakova EV, Zghuang T, Li T, Fang Q, Han J, Qiao H 2017 The Gas6 gene rs8191974 and Ap3s2 gene rs2028299 are associated with type 2 diabetes in the northern Chinese Han population. Acta Biochim Pol 64(2):227-231.

Kirchhausen T, Owen D, Harrison SC 2014 Molecular structure, function, and dynamics of clathrin-mediated membrane traffic. Cold Spring Harb Perspect Biol 6(5):a016725.

Kooner JS, Saleheen D, Sim X, Sehmi J, Zhang W, Frossard P, Been LF, Chia KS, Dimas AS, Hassanali N, Jafar T, Jowett JB, Li X, Radha V, Rees SD, Takeuchi F, Young 
R, Aung T, Basit A, Chidambaram M, Das D, Grundberg

E, Hedman AK, Hydrie ZI, Islam M, Khor CC, Kowlessur S, Kristensen MM, Liju S, Lim WY, Matthews DR, Liu J, Morris AP, Nica AC, Pinidiyapathirage JM, Prokopenko I, Rasheed A, Samuel M, Shah N, Shera AS, Small KS, Suo C, Wickremasinghe AR, Wong TY, Yang M, Zhang F, Diagram, MuTher, Abecasis GR, Barnett AH, Caulfield M, Deloukas P, Frayling TM, Froguel P, Kato N, Katulanda P, Kelly MA, Liang J, Mohan V, Sanghera DK, Scott J, Seielstad M, Zimmet PZ, Elliott P, Teo YY, McCarthy MI, Danesh J, Tai ES, Chambers JC 2011 Genome-wide association study in individuals of South Asian ancestry identifies six new type 2 diabetes susceptibility loci. Nat Genet 43(10):984-989.

Kumar S, Stecher G, Tamura K 2016 MEGA7: Molecular evolutionary genetics analysis version 7.0 for bigger datasets. Mol Biol Evol 33(7):1870-1874.

Le Roy C, Wrana JL 2005 Clathrin- and non-clathrinmediated endocytic regulation of cell signalling. Nat Rev Mol Cell Biol 6(2):112-126.

Li Y, Chang M, Abar O, Garcia V, Rowland C, Catanese J, Ross D, Broder S, Shiffman M, Cheung R, Wright T, Friedman SL, Sninsky J 2009 Multiple variants in toll-like receptor 4 gene modulate risk of liver fibrosis in Caucasians with chronic hepatitis C infection. J Hepatol 51(4):750-
757.

Mercer J, Schelhaas M, Helenius A 2010 Virus entry by endocytosis. Annu Rev Biochem 79:803-833.

Nishiya T, Kajita E, Miwa S, Defranco AL 2005 TLR3 and TLR7 are targeted to the same intracellular compartments by distinct regulatory elements. J Biol Chem 280(44): 37107-37117.

Park W, Rengaraj D, Kil DY, Kim H, Lee HK, Song KD 2017 RNA-seq analysis of the kidneys of broiler chickens fed diets containing different concentrations of calcium. Sci Rep 7(1):11740.

Robinson MS 2004 Adaptable adaptors for coated vesicles. Trends Cell Biol 14(4):167-174.

Weber F, Wagner V, Rasmussen SB, Hartmann R, Paludan SR 2006 Double-stranded RNA is produced by positivestrand RNA viruses and DNA viruses but not in detectable amounts by negative-strand RNA viruses. J Virol 80(10):5059-5064.

Zhang M, Song K, Li C, Chen Z, Ding C, Liu G 2015 Molecular cloning of Peking duck Toll-like receptor 3 (duTLR3) gene and its responses to reovirus infection. Virol J 12:207.

Received Mar. 5, 2019, Revised Mar. 13, 2019, Accepted Mar. 13, 2019 
